Article in Diogenes, Sage Publishers $(62.1,2016)$

\title{
European co-production funds and Latin American Cinema: Processes of othering and bourgeois cinephilia in Claudia Llosa's La teta asustada.
}

\author{
Deborah Shaw \\ University of Portsmouth
}

Over the last ten years, a substantial number of Latin American directors have made films that have been supported by European funding bodies; they that have been showcased in festivals around the world, and in some cases distributed internationally1. These funds have brought women filmmakers from Latin America into the spotlight, and those who have benefitted from support with production (and in many cases post-production) include the Peruvian director Claudia Llosa, the Argentinean directors Lucía Puenzo, Lucrecia Martel and Celina Murga, the Paraguayan Paz Encina, the Chilean Dominga Sotomayor, and the Mexican Yulene Olaizola, among others. This creates the curious scenario whereby Europe is instrumental in co-creating a boom in Latin American women's filmmaking, a scenario that raises a number of interesting questions and ties in with wider debates around European subsidies for 'world cinema'. Is this a form of neocolonial European intervention in the cultural production of less developed nations? Is Europe looking to the world to supply a stream of exotic imagery for its entertainment? Should European funding bodies be celebrated for enabling the production of important films that would either not be made, or would have much lower budgets, and a much less visible trajectory without them? These questions will be addressed through the specific case of one of the most high profile and controversial Latin American directors, Claudia Llosa, whose films have won awards on the international festival circuit while provoking disquiet among Peruvian and Latin Americanist critics for what some see as a Westernising and racist representations of poor Peruvians. I consider the key positions in the European funding of 'world cinema' debates, and then position a reading of La teta asustada/The Milk of Sorrow (2009) within these debates. I begin with a brief discussion of Llosa's first film Madeinusa (2006), as this film initiated the controversies surrounding Llosa's depiction of indigenous Peruvians. Do Llosa's films confirm the critical positions by being subject to a process of othering for a European cinephile festival audience? Or, do they challenge neo-colonialist readings of European co-funded projects? What findings can be drawn through the focus on single film texts? I warn against generalising conclusions and contrast Llosa's approach with that of Lucrecia Martel and Lucía Puenzo in particular through their diverse approach to representations of ethnicity and class.

\section{The Funding Context, 'World Cinema' and the Debates}

I would like to thank Sarah Barrow for her helpful and incisive comments on the first draft of this article. 
Before addressing the key questions and debates, I want to first set the scene in terms of European co-productions of Latin American art cinema, and in particular films directed by women. A close look at the credits of some of the best-known texts reveals that the same funding bodies and production companies often recur from film to film. These are from a range of European funders such as the Dutch Hubert Bals Fund linked to the Rotterdam Film Festival; the French Cinéfondation, programme aligned with the Cannes film festival; Fonds Sud, now Aides aux Cinéma du Monde and managed by the French CNC (Centre National du Cinéma et de l'Image Animée) and the Institut Français; the German World Cinema Fund of the Berlin Film Festival; and the Spanish-led, Hispanic Programa Ibermedia. A selection of private companies also feature in the credits of many art films from Latin America: some examples are the Spanish production company El Deseo, the production company founded by Pedro and Agustín Almodóvar in 1985; Wanda Visión, the Spanish production and distribution company; and Pyramide Films, the French production and distribution company, with all three companies specializing in quality 'world' art cinema. This funding landscape also includes European television companies that have ventured into art film production such as Arte France Cinéma, Canal Plus and Televisión Española.

That is not to say that national film agencies are no longer supporting 'local' films, rather they constitute one funding stream in what is a complex make up of financing arrangements. For instance, the Argentinean Instituto Nacional de Cine y Artes Audiovisuales (INCAA) has co-produced films by Lucía Puenzo, and along with European funders has supported films by its best known young auteurs, Pablo Trapero, Israel Adrián Caetano and Lisandro Alonso. Claudia Llosa won some money from the (now defunct) Peruvian national fund Conacine for Madeinusa and La teta asustada following foreign support for the films (Barrow 2013: 202). In the case of Mexico, the national film agency IMCINE often appears as one of the producers alongside funders such as Hubert Bals or the World Cinema Fund as seen in the case of one of the best known Mexican art directors, Carlos Reygadas. To give another example of earlier funding for a Latin American woman director, Perfume de violetas: nadie te oye/Violet Perfume: No One Is Listening (2001) by Marisa Sistach, is a Mexican/Dutch coproduction with IMCINE and Hubert Bals featuring in the credits.

In fact, a single film is often the recipient of funds from a wide selection of these funding bodies. In the case of the focus film in this article, La teta asustada had a small amount of Peruvian support, but relied on Spanish funding, including finance from Wanda Visión, the Catalan government arts body, the Generalitat de Catalunya - Institut Català de les Indústries Culturals (ICIC), the Ministry of Culture, Televisió de Catalunya (TV3) and Televisión Española (TVE). It was also supported by the Programa Ibermedia. NonSpanish funds were secured through the Swiss Visions Sud Est (linked with Fribourg Film Festival, and funded in turn by the Swiss Agency for Development and Cooperation), the World Cinema Fund and the Media Programme of European Community.

Critics who have engaged with the reconfigured production landscape of much of the recent 'world cinema' that is coming to prominence via the festival circuit are rather divided in terms of its ethical dimensions. The term 'world cinema is a contested term of questionable value as has been well documented (Dennison and Lim 2006, Grant and 
Kuhn 2006, Nagib 2006), and which I have discussed elsewhere (Shaw 2011). However, for the purposes of this article its use is adapted from Elsaesser's understanding of it as a category constructed through the festival film circuit:

World cinema $[\ldots]$ is a category conceived of and circulating from the point of use of distribution and exhibition which in turn determines the profile of production. For instance, if we look at marketing and distribution, it is evident that the label world cinema gains its primary currency, as already noted, through the international festival circuit (Elsaesser 2005:104).

This can be extended to films that have received European sponsorship from funding bodies (in addition to other sources of private and state funds) primarily because they have a ready market in the festival circuit, which, in the best of cases, will result in distribution on non-English language art cinema circuits.

A number of recent articles have initiated debates about the power dynamics of European bodies giving grants to poorer nations that were in many cases former colonies of the funders. Certain scholars have critiqued, from a post-colonial perspective, the way that they perceive that funding shapes and distorts cultural production in non-European countries (Halle 2010, Friedman 2013, Ross 2011). An additional criticism is that European funding nations co-opt and claim ownership over films from around the world (Ostrowska 2010). Other scholars have seen funding bodies in more progressive terms, and have commended the way that they promote diverse representations, and provide opportunities and agency to the filmmakers themselves (Göktürk, 2002; Shaw 2013). Falicov (2013) has stressed the benefit of training, assistance and partnerships to inexperienced filmmakers, but also notes the role of the funders in privileging a "globalized art house aesthetic".

One of the difficulties in reaching a consensus is that theorists are attempting to make judgements about the effects of funding bodies whose remit is a very broad terrain, with support for films from Asia, the Middle East, Eastern Europe, Africa and Latin America, and funders across Europe. I would argue that specific cases need to be examined and conclusions drawn in relation to these examples, without attempting to extrapolate from these a vision of the entire funding landscape. Thus, Friedman (2015) can argue, based on her specific knowledge, that European interventions in Israeli and Palestinian filmmaking have taken an interventionist approach and attempt to shape filmmaking initiatives with the result that Palestinian voices have been distorted2. Elsewhere I have argued that programmes such as Hubert Bals, the World Cinema Fund, and Cinéfondation have created spaces for Argentinean queer art films directed by women, that investigate sexuality and non-traditional families. XXY (Puenzo, 2007) and La niña santa/The Holy Girl (Martel, 2004) provide examples of films that, while chiming with identity construction in Europe, are not subject to negative distortions, and the filmmakers are

Friedman bases her conclusions on an analysis of the production of 5 Broken Cameras (2011) directed by the Palestinian Emad Burnat and the Israeli Guy Davidi. 
enabled to develop their own auteurist visions (Shaw 2013).

Nonetheless, there is a clear sense for a number of critics that an exoticising or othering process is intrinsic to the funding process. Randal Halle, for instance, argues that coproductions inevitably lead to a form of Orientalism whereby European and US audiences are given stories we desire and provided with representation of 'distant strangers', with a focus on cultural difference (Halle 2010: 314): Festival and art cinema audiences are provided with a set of 'cultural texts that speak the truth of the other on behalf of that other' (ib.:314). Ross (2011) argues that Latin American films supported by the Hubert Bals Fund follow certain expectations associated with 'third world' 'underdeveloped' nations. Thus, while she celebrates the enabling potential of the finance, she argues that images of poverty, crime and violence and processes of underdevelopment dominate. Likewise Thomas Elsaesser, while not referring explicitly to European funding, echoes Halle's argument through his assertion that 'world cinema' is a form of cultural neo-colonialism (Elsaesser 2005: 509). He writes:

World cinema [. . . ] is always in danger of conducting a form of autoethnography, and promoting a sort of self-exoticization in which the ethnic, the local or the regional expose themselves, under the guise of self-expression, to the gaze of the benevolent other, with all the consequences that this entails. World cinema invariably implies the look from outside and thus conjures up the old anthropological dilemma of the participant observer being presented with the mirror of what the "native" thinks the other, the observer wants to see (ib.: 510).

\section{Claudia Llosa - A short note on Madeinusa}

The award winning Claudia Llosa has been accused by some academics and many in Peruvian film circles of precisely the forms of representations that Halle, Ross and Elsaesser have seen as characterizing some elements of 'world cinema'. As María Chiara D'Argenio (2013: 2) notes Llosa's films are more interested in addressing a global than a national audience, and have, as a result, offended many within Peruvian critical circles. Both Diana Palaversich (2013) and Sarah Barrow (2013) have summarised the controversies surrounding Llosa's films. Palaversich (2013: 489) notes that Llosa has been accused of 'perpetuating racist colonial stereotypes of primitive and perverted natives', although she defends her from these judgements and produces a feminist reading of the director's first film Madeinusa. Barrow (2013: 204) explains that Llosa 'has come in for some quite vitriolic criticism - from those who have condemned her debut film as naïve at best and racist, sexist, Eurocentric, exoticist at worst'.

The criticisms are most obviously applicable to the director's first film Madeinusa that features a faux ethnographical gaze at Andean customs and festivities, invented by the writer/director, but that appear to the uninformed viewer to be entirely authentic. Despite its national and regional focus it was 'Made-in-Europe' as well as 'Made-in-the-USA' as it received support from the Sundance Screenwriters' lab in addition to Spanish production funding; it was also supported by the World Cinema Fund. This clearly branded it a festival film and ensured it was set itself up for festival circulation, where it won a number of awards (see Barrow 2013: 202). 
The film takes place in the fictional village of Manayacuna and focuses on the inhabitants' interpretation of the Easter celebrations of Tiempo Santo (Holy Time) in which God (Jesus) has died and has yet to be resurrected, and the villagers are obliged to sin through a range of means, including consuming vast amounts of alcohol, committing incest, stealing from each other, desecrating tombs and generally breaching all social conventions. The mayor of the village Don Cayo has been waiting for this time to have sex with his teenage daughter who carries the ideologically loaded name of Madeinusa. It is no wonder that she is desperate to leave for the 'civilised' world of Lima. The film broadly corresponds to a form of popular art cinema that rests on a tourist gaze: the desire of viewers to consume 'authentic', hidden landscapes and its Quechua people led by a filmmaker in the form of tourist guide3.

The film problematizes, to a degree, a simplistic reading of the power dynamics by introducing a Western white Peruvian with another ideologically loaded name, Salvador (Saviour) as an outsider who happens upon the village. The film does subvert any sense of the saviour complex when Madeinusa and her sister frame the 'gringo', as he is known, for the murder of their father. Nonetheless, the viewer sees the 'backward' villagers through his urban and modern eyes, and the lack of an identificatory gaze with the Quechua speaking locals or Madeinusa calls to mind Elsaesser and Halle's critiques of 'world cinema'. As D'Argenio argues, the 'character is built according to a colonialist discourse' (2013:15), and for her, neither Madeinusa nor Fausta (the protagonist of La teta asusatada) escape their condition of ethnic other based on long established Western Peruvian stereotypes of 'Indians' (15). Nonetheless, Llosa is not engaged in selfexoticising representations as she is from the white cultural elite and has made her home in the European cultural capital of Barcelona. As Sarah Barrow (2013: 204) notes: 'The fact that the film offered a disconcerting portrayal of 'authentic' Peru as imagined by a director/writer from an urban, Europeanized background, with limited experience of the Andes herself, was cause for criticism amongst some'.

\section{La teta asustada}

As with Madeinusa, La teta asustada makes the focus of the film the encounter between rural and urban Peru and the white Western upper classes. However, perhaps as a result of the controversies stirred by her first film, Llosa is more willing to probe the power dynamics of the relationship through a close analysis of ethnic and class divisions within the country through an examination of the mistress/servant dynamic. In this it has a lot in common with much recent Latin American cultural production that places class and ethnic divisions at the centre of their narratives through a focus on maids and their employers. A few examples of many include La ciénaga/The Swamp (Martel, 2001); El niño pez/The Fish Child (2009), La nana/The Maid (Silva 2009), and Doméstica/Housemaids (Máscaro, 2012), a Brazilian documentary made from the work of 7 adolescents who were asked to film their maids over 7 days.

These are ideas that I have developed elsewhere (Shaw, 2011, 2013). 
Initially it appears as if La teta asustada will focus on the legacies of the war between the communist organisation, Sendero Luminoso (Shining Path) and the state, and the peasant victims of this conflict embodied in Fausta (Magaly Solier) and her mother Perpetua (Barbara Lazon) who dies early on in the narrative. This conflict is at the root of the supposed sickness suffered by Fausta, 'la teta asustada', literally translated as 'the frightened tit/breast' (it is given a more poetic rendition of The Milk of Sorrow in its English language release). It afflicts children of the rape victims of the conflict, and is the reason for Fausta's melancholic state and for her terror of being raped. Kimberly Theidon's book on the armed conflict in Peru chronicles the rape of women in Andean villages of Ayacucho (Theidon 2009). She notes that it was mainly the armed forces that committed group rape, while Sendero Luminoso would kidnap the young women for their personal gratification (Ugaz 2009). She identified the concept of 'leche de rabia' (milk of anger) or 'leche de miedo' (milk of fear) that the violated women believed that they would pass to their children (Ugaz 2009). Theidon herself translated this from Quechua to 'la teta asustada' in Spanish (Ugaz 2009), presumably as she felt it had more impact. Nonetheless, the historical context to the story is presented as a broad background and viewers learn nothing of the conflict or who is responsible for the rapes. Her uncle does tell the doctor who treats his niece, that 'con el terrorismo nació Fausta' (Fausta was born with terrorism), thus indirectly linking Sendero Luminoso with the rape. Rather than focusing on the violence of former times, the film sets up a series of encounters between urban and rural Peru, and between white, wealthy middle class criollos (Peruvians of Spanish ancestry), and those of poor Andean origins, and is thus more interested in ideas of identity in contemporary Peruvian society, while the links to the Colonial period are referenced more directly that the more recent period of conflict of the 1980s and 1990s.

This premise would seem to suggest a sensitive exploration of class and ethnic divisions in Peru, particularly as the narrative has at its centre the relationship of Fausta and her wealthy employer, Aída, the operatically named celebrated pianist/composer. Class and ethnic exploitation is foregrounded in the narrative, as Aída (Susi Sánchez), parasitically exploits Fausta's ability to write songs, which she incorporates, without acknowledging her sources, into her own 'nativist' concert repertoire. The film thus represents a reworking of neo-colonial appropriation of national 'authentic' culture. Nonetheless, the film has also come in for criticism from those who are sensitive to issues of cultural representation. D'Argenio (2013: 6) for instance argues that in both Llosa's Peruvian feature films:

the representation of indigenous people reformulates categories and tropes articulated by nineteenth-century colonialist discourses, which described indigenous people as inferior subjects with, on the one hand, a child-like ingenuousness and, on the other, degenerate behaviour.

The indigenous world is, for D'Argenio, coded as rooted in a rural Andean tradition of backwardness and irrationalism (id., ib.), and this can be overcome by accepting the civilization offered by a modern urban society (ib.:7). Aída is cold and manipulative and, as argued, engages in forms of neo-colonial exploitation, illustrated by the fact that she gives Fausta a pearl in exchange for each song she sings to her. Nonetheless, it is unclear 
whether this Fausta, unlike her namesake of German legend, has a soul to sell to her diabolical mistress, and in this lies a view of 'the native' that chimes with Elsaesser and Halle's notions of exoticism and world cinema. Jeffrey Middents (2013: 158) refers to similar criticism within Peru, and notes César Hildebrandt's views expressed in Primera Perú, that La teta asustada is, 'all folkloric and tightly wound, everything done to elicit shouts of laughter, horror and condescension between responsible Europeans, well-worn NGOs and lovers of exoticism'. Thus, a film funded by Europe, and acclaimed in Europe and the US comes to Peru where it is both a box office hit, and, like Madeinusa, the subject of controversy by cultural critics 4 .

The film presents a primitivist depiction of the Quechua speaking protagonist, with the belief in 'la teta asustada' embodied in Fausta whose acting brief appears to stipulate a soulless performance. She is vacuous, fearful of male strangers and childlike; one of the few times we see her smile is when watching cartoons in a break at her employer's home. In this way, she confirms D'Argenio's view of Llosa's predilection for infantilized Quechua characters who correspond to visions of underdevelopment. As Fausta's uncle (Marino Ballón) explains to the doctor Fausta visits after fainting, the children of women who have been raped in the conflict between the state and the Shining Path guerrilla fighters are born without a soul, because 'it hid in the earth in terror' ('porque de susto se escondió en la tierra'). This terror is also meant to explain Fausta's decision to place a potato inside her vagina in order to protect her from rape. This is an approach that approximates magical realism in that the characterisation and belief system appear to come from the worldview of the rural, poor Peruvians: for Fausta and her family 'la teta asustada' is a genuine condition that explains her empty identity.

It is unclear whether Fausta does indeed have a soul and her story is that of a young woman in search of an identity through the recuperation of her soul. She informs her only friend, the gentle gardener Noé (Efraín Solís) that she has to walk close to the walls on her way home to the city slums, termed locally as pueblos jóvenes or young towns (Middents 2013: 156). This is because she learnt in her mother's village that the lost souls will steal those of the living; indeed this was, Fausta states, the cause of her bother's death. A character without a soul is a character without agency and Fausta rarely escapes her condition of passive victim characterised by material, educational and intellectual poverty.

The difference between this form of magical realism and that espoused by such well know Latin American authors as Gabriel García Marquez, Miguel Ángel Asturias and Isabel Allende, is that Llosa's vision has a negative judgement of the characters' worldview that the novelists do not share. D'Argenio notes that 'despite having moved to the capital city, the Andean culture is still presented as the place of primitive/irrational belief and practices' (5). Both the faith in the 'teta asustada' and Fausta's practice of inserting a potato in her vagina illustrate this worldview. This is established very early on

Middents (2013: 158) notes that this film was also defended in Peru for its aesthetic qualities. 
in the film where Fausta's decision is explained through the medical discourse of the benevolent doctor, immediately pathologising it. He tells Fausta's uncle that he has seen cases before but in older women, thus linking it to community practices rooted in ignorance and tradition. Her refusal to be treated medically also results in Fausta assuming the blame for her own condition (an inflamed uterus as a result of the bacteria).

The idea of the protagonist having a potato inserted in her vagina is linked via her mother to a Quechua rural, village identity. It generates an image of exotic disgust as Fausta's beauty is tainted by its juxtaposition with the sprouts that grow and protrude from her vagina, that she is shown clipping. Thus, the urban Euro-Peruvian Llosa creates a rural indigenous other to generate disgust and alienation for implied, sophisticated audiences. The alienating device of the potato also allows for the 'happy ending' and the modern concept of self-development when Fausta at the close of the film begs Noé to 'get it removed from inside me'. The suggestion is that Fausta is on the route to civilisation and is prepared to abandon her primitive and harmful rural beliefs. She will bury her mother, symbolically named Perpetua, and thus be free of her presence that has so damaged her.

Perpetua is coded to represent memory and the adherence to tradition, illustrated well in the words sewn on to her sleeve, 'no me olvides' (do not forget me). The disgust for the primitive represented by Perpetua and her belief systems is also maintained for the viewer through the presence of the dead woman. Llosa tests her audience's tolerance levels by showing Fausta sleeping next to her dead mother and she even reveals the hair of the dead woman coming off in thick strands as her daughter strokes it. Her corpse is kept under Fausta's bed, while she tries to accumulate the money needed to bury her in her Andean village. In this way, memory is not represented as something positive as is the case in so much Latin American cultural production, but as a form of underdevelopment, holding Fausta back from acquiring a modern identity.

It is worth noting that an entirely different reading is provided by Juan José Beteta (2009). In his defence of the film he argues that it presents Fausta on a journey of empowerment and that this is achieved without any recourse to othering processes or a separation between archaic, primitive and pintoresque representations and modernity5. However Beteta does not provide any filmic evidence for these assertions, and while Fausta does overcome her terrors, these are rooted in traditional ignorance that are, as I have argued, associated with rural, backward and primitive identities. Thus, Fausta is multiply othered: by her urban family who prefer to speak Spanish to Quechua, Fausta's first language, and seek a modern city life embodied in their tacky wedding party business; by her aristocratic employer who sees her of no worth while stealing her 'natural' indigenous musical gifts; and also by the filmmaker who never quite allows her protagonist agency and also exploits her primitivism for the entertainment of the festival and urban art cinema audiences for whom she has been created.

Sin embargo, no hay en el cine de Llosa una escisión entre lo "arcaico", "primitivo" y "pintoresco", de un lado, y un comportamiento "moderno", del otro (Beteta 2009). 
While I have argued against an application of Randal Halle's theories of the problems of European funded 'world cinema' in a reading of films by Lucía Puenzo and Lucrecia Martel (Shaw 2013), it is hard to dispute some of his key points in the case of Llosa's films and in the particular case of La teta asustada. In addition to Halle's arguments relating to the creation of 'distant strangers' in films supported by festival funders (Halle 2010: 304), Halle has argued that conditions of production are masked in films supported (ib.:313). The othering processes at play have been discussed, while the film was taken as representative of Peruvian culture in the world with little acknowledgement of its multinational production condition funded sources, seen primarily in the fact that it was chosen to represent the country at the 2009 Academy Awards, and in the way critical reviews pay little attention to the European funding context.

Nonetheless, it is not only the indigenous Andean Fausta who is othered in La teta asustada, but also the colonial class through the representation of Señora Aída and her big house on the top of the hill. The film stages a fascinating encounter between the worlds of Peru inhabited by the different classes and ethnic groups, and delivers striking images of these two sites of Peruvian life. Both Middents (2013) and Beteta (2009) have praised the technical skills of Llosa and her cinematographer Natasha Braier, and as a team they paint a visually impressive portrait of Peru and its characters with their use of the long take, stylishly composed mise-en-scène and attention to the landscapes offered by Andean Peru in Madeinusa and bustling colourful poor urban spaces of Lima's outskirts. The primacy of the image that characterizes art cinema is certainly on display in Llosa's work. This in itself clearly does not mitigate against accusations of Eurocentric visions of indigenous Peru. Yet, La teta asustada does provide its own judgement on the Eurocentric dominance within Peru by the Criollo class.

Beteta (2009) explains that the film's location is Manchay, an area next to San Juan de Lurigancho that historically and symbolically represents three spaces within Lima: the urban, the Andean and the colonial. The film imagines the encounters between three groups: Fausta and her mother, recent migrants from rural, Andean Peru for whom material possessions are of little concern; the urban poor represented by her Uncle Lúcido and his family, more established rural migrants, whose ambitions are represented in the wedding presents, (a mixture of religious iconography, traditional gifts such as chickens and modern luxuries such as new chairs and sofa); and Fausta and Señora Aída. While I have critiqued the passive and primitivist representation of Fausta, there are moments of brilliance in the encounter staged between these two figures from entirely separate worlds that serve to highlight the way the ruling white European classes dominate and negate the identities of the servant classes.

At several points on entering the gloomy colonial mansion, Fausta sees an image of herself distorted in the portrait of a colonial ancestor (see figure 1). The headless military figure casts its ghostly shadow over a de-saturated Fausta, also visualised as a ghostly figure drained of life. The colour palette here and for the casa grande (the big colonial house) is made up of olive greens and dull browns, colours of history, enclosure and privilege, that contrast with the vibrant colours of the marketplace outside the walls of the 
house (see figure 2). Aída is first seen among these photographs of historical matriarchal and military patriarchal figures, fixing a picture hook on to the wall (see figure 3 ). She does not even look at Fausta who makes her way almost paralysed with fear over to her, and when Aída does speak to her she negates her new maid's existence a second time by calling her Fina, the name of her other housemaid. Fausta, overcome by the weight of so much history in which she has no visible presence, suffers a nosebleed and runs away. Trembling she can only find herself again by singing to herself in Quechua (in the song she invents, she tells herself to sing pretty things to hide her fear and pretend that it does not exist). This exacerbates the final theft, Aída's plagiaristic appropriation of another of her maid's compositions for her own piano recital. The protagonist's Faustian pact with her mistress whereby she exchanges songs for pearls does not even result in the attainment of any gain, as Aída reneges on her promise when her maid dares to speak claiming that Aída's audience enjoyed the music. The fact that she has dared insinuate ownership over the music leads Aída to erase her from her life and eject her from the car they are travelling in. Fausta is never given the pearls which results in her one act of defiance, as she enters the house to take what she believes to be rightly earned. These scenes are powerful and illustrate with the economy of cinematic imaging differences of class, race, language, material possessions, and identity.

\section{Conclusion}

Yet, while the differences between the classes within in Peru are illustrated, the difference of the characters to the implied viewers are also emphasised, and it is significant that there is no evidence of any urban middle classes in this portrait of modern Peru. Throughout La teta asustada both Señora Aída and Fausta are othered, with the implied bourgeois spectator providing the meaning and the judgement on these two alien worlds. The colonial house is high above the settlement where Fausta lives at the bottom of the hill, and 'we', the implied urban 'cosmopolitan' viewers, are located in between these two spaces. Thus, the film harnesses a middle class urban gaze that will produce a judgement on the primitive and exploitative classes we are presented with in La teta asustada. Here it is worth returning to the spaces in which the film was received to identify the actual viewers targeted. As Jeff Middents notes (2013: 158), the film was only a success in Peru following its exposure in Europe and the US. It was awarded the Golden Bear for Best Feature at the Berlin Film Festival in 2009, and a subsequent Oscar nomination. It received a number of nominations and awards from around the world in 2009 including the Spanish Goyas, the Montréal Festival of New Cinema, and the Mexican Arieles (see 'The Milk of Sorrow Awards, 2009' for a full list of nominations and results). It was released principally to festival audiences around the world in 2009/2010 including the Berlin International Film Festival, the Istanbul Film Festival, the Danish CPHPIX Festival, the Czech Karlovy Vary International Film Festival, the Croatian Motovun Film Festival, the South Korean Pusan International Film Festival, the London Film Festival, and the Palm Springs International Film Festival (for full details, see 'The Milk of Sorrow Release Info'). Thus, following on from the production contexts seen in the funding arrangements outlined above, it is clear that a specific international cinephile festival audience was targeted for this feature. The othering processes are then directed to these viewers who can comfortably judge the ignorance of Fausta and the exploitative tactics of Señora Aída from the position of bourgeois cinephilia. 
Despite the fact that La teta asustada appears to illustrate very well key aspects of Halle and Elsaesser's theories on 'world cinema' and the relationship between funding bodies and processes of othering, there is, as I argued at the start of this article, a danger of drawing generalising conclusions about the relationship between production contexts and cultural production based on a single or even a selection of texts chosen to fit a specific thesis. Therein also lie the limitations implicit in the notion of 'world cinema' as there can clearly only be plurals in cinematic production from around the world, even if the same funding bodies are instrumental in their production. That Claudia Llosa's European co-productions construct a particular vision of indigenous and upper-class Peruvian identity does reveal a certain willingness to consume a Western bourgeois inflected take on that identity both by director, funders and her festival viewers. However, there are many other films from Latin America and other parts of the world that do give their protagonists more agency and avoid visions made to reinforce Eurocentric prejudices.

Bourgeois cinephilia is, of course, at the root of the film festival experience, and of much art film spectatorship (and of academic scholarship seen here), but that does not mean processes of othering built on nativism and caricatured images of the ruling classes are part and parcel of films from around the world supported by the festival film funds. Perhaps a way forward here can be found in an analysis of what directors choose to represent and where they position themselves. In an interview the celebrated Argentinean director, Lucrecia Martel, said the following:

Yo me ocupo de la clase media, que es la que conozco y a la que detesto, y también la que me da mucha compasión. Los otros aparecen, pero con el respeto de no meterme con sus emociones. [. . .] Prefiero no meterme en mundos que me son ajenos, por respeto y por ignorancia (Aldazábal, 2004)

I am concerned with the middle class, which is the class that I know and detest, and for which I feel much compassion. The other classes make an appearance, but I respect them too much to not interfere with their emotions [. . . ] I prefer not to interfere in worlds that are unknown to me, out of respect and my ignorance (my translation).

Martel's films, La ciénaga/The Swamp (2001) La niña santa/The Holy Girl (2004) and La mujer sin cabeza/The Headless Woman (2008) take the point of view of middle class characters. In their dealings with the other classes, the writer/director demonstrates her protagonists' partial views and prejudices. This is particularly apparent in La ciénaga which documents a decadent bourgeoisie in decline, unable to treat themselves or the servant class that props them up with any respect. Likewise, Lucía Puenzo whose films are also co-financed by European funding bodies has made the relationship between diverse classes and ethnic groups the subject of her film El niño pez/The Fish Child (2009)6. By interrogating the relationships and power dynamics through flawed middle

I have written about the way she de-others her intersex protagonist, Álex, in XXY elsewhere (Shaw 2013). Here too the focus is on a middle class family. 
class protagonists, the film broadly shares Martel's concerns about the representation of 'the other'. The othering of the servant class that takes place in the film is done by flawed characters and is presented as a problem that the film seeks to raise. In El niño pez, the servant La Guayi (Mariela Vitale) is imprisoned after Lala (Inés Efrón) kills her own father, a successful writer. La Guayi's guilt is assumed both by the family and by a system that punishes the servant over a middle class girl. The film explores whether a passionate sexual love between two young women can overcome class and ethnic differences, and offers tentative positive possibilities seen in the shared framing devices used to tell their story, and equal value ascribed to their identities. While La Guayi's Paraguayan identity is explored and the myths associated with her home town recounted, she is never seen as primitive or underdeveloped and is a strong young woman who fights for her survival; in other words Puenzo uses none of the exoticising strategies Llosa uses to create Fausta. Telling the stories of one's own social world is certainly one of the ways to avoid exoticising traps lying in wait for filmmakers supported by European funding bodies, as is the need for more stories to be made by people with intimate, insider knowledge of the worlds they are recreating. Representation has always been a thorny question and will continue to be so as long as filmmaking, money and power dynamics are so closely interwoven.

Sources

Aldazábal C. (2004) “Desdomesticar la percepción: Entrevista a Lucrecia Martel”, http://www.revistateina.es/teina/web/teina6/cine4.htm

Barrow, S. (2013), "New configurations for Peruvian cinema: The rising star of Claudia Llosa", Transnational Cinemas, 4: 2: 197-215.

Beteta, J.J. (2009) "La teta asustada de Claudia Llosa", Cine Encuentro, March 17, http://www.cinencuentro.com/2009/03/17/la-teta-asustada-de-claudia-llosa-parte-i/

D’Argenio, M. C. (2013) “A contemporary Andean type: The representation of the indigenous world in Claudia Llosa's films", Latin American and Caribbean Ethnic Studies, 8, 1: 5-23.

Dennison, S. and Lim, S. H. (2006) "Identity, Culture and Politics in Film: World Cinema as a Theoretical Problem", in S. Dennison and S. H. Lim (eds), Remapping World Cinema: Identity, Culture and Politics in Film, pp. 1-15. London: Wallflower Press.

Elsaesser, T. (2005) European Cinema: Face to Face with Hollywood. Amsterdam University Press: Amsterdam. 
Falicov, T. (2013) "Cine en Construcción (Films in Progress): How Spanish and Latin American Filmmakers Negotiate the Construction of a Globalized Art House Aesthetic", Transnational Cinemas, 4.2: 253-271.

Friedman, Y. (2015) 'Guises of Transnationalism in Israel/Palestine: A few notes on 5 Broken Cameras', Transnational Cinemas, 6.2 (forthcoming).

Göktürk, D. (2002) "Anyone at Home? Itinerant Identities in European Cinema of the 1990s." Framework 43.2: 201-212.

Grant, C. and Kuhn, A. (2006) Screening World Cinema: A Screen Reader. London: Routledge.

Halle, R. (2010) "Offering tales they want to hear: Transnational European Film Funding as Neo-Orientalism", in R. Galt and K. Schoonover (eds), Global Art Cinema, pp. 303319. Oxford: Oxford University Press.

Middents, J. (2013) "The first rule of Latin American cinema is you do not talk about Latin American cinema: Notes on discussing a sense of place in contemporary cinema", Transnational Cinemas, 4.2: 147-164

Nagib, L. (2006) "Towards a Positive Definition of World Cinema". In S. Dennison and S. H. Lim (eds), Remapping World Cinema (pp. 30-37). London: Wallflower Press

Ostrowska, D. (2010), "International Film Festivals as Producers of World Cinema", Cinéma \& Cie, 10, 14-15: 145-150.

Palaversich D. (2013), "Cultural dyslexia and the politics of cross-cultural excursion in Claudia Llosa's Madeinusa", Bulletin of Hispanic Studies, 90, 4: 489 - 503.

Ross M. (2011) "The film festival as producer: Latin American Films and Rotterdam's Hubert Bals Fund." Screen, 52, 2: 261-267.

Shaw D. (2011) "(Trans)National images and cinematic spaces: The cases of Alfonso Cuarón's Y tu mamá también (2001) and Carlos Reygadas' Japón (2002)." Iberoamericana 44: 117-31.

Shaw D. (2011) "Babel and the Global Hollywood Gaze." Situations: Project of the Radical Imagination, 4.1:11-31

Shaw, D. (2013) "Sex, texts and money, funding and Latin American queer cinema: the cases of Martel's La niña santa and Puenzo's XXY', Transnational Cinemas, 4.2: 165184.

"The Milk of Sorrow Awards, 2009" http://www.imdb.com/title/tt1206488/awards?ref_=tt ql_4

"The Milk of Sorrow (2009) Release Info" http://www.imdb.com/title/tt1206488/releaseinfo?ref_=tt_q1_9 
Theidon K. (2004) Entre Prójimos: El conflicto armado interno y la política de la reconciliación en el Perú. Lima: Instituto de Estudios Peruanos.

Ugaz, P. (2009). "Es un sueño para cualquier investigador que tu trabajo motive a los demás”, Terra Perú, March 3, http://www.terra.com.pe/noticias/articulo/html/act1659267.htm

Van Hoeij, B. (2009) "Review 'The Milk of Sorrow', Variety, February 14, http://variety.com/2009/film/reviews/the-milk-of-sorrow-1200473657/ 